\title{
Policy Traps: Consumer Subsidies in Post-Crisis Argentina
}

\author{
Tomás Bril-Mascarenhas • Alison E. Post
}

Published online: 10 June 2014

(C) The Author(s) 2014. This article is published with open access at Springerlink.com

\begin{abstract}
Developing countries devote significant resources to lowering consumer prices for basic goods and services such as food and electricity. Theories of the welfare state only partially elucidate why consumer subsidy regimes grow so large and become entrenched. While the welfare state literature stresses how concentrated, organized beneficiary groups push for the expansion and protection of well-known programs such as pensions, the developing world's consumers are atomized, and subsidies themselves are of low visibility. The size and durability of consumer subsidy regimes stem primarily from political uncertainty and price shocks that provide politicians with strong incentives to avoid blame for repeal. Over time, environmental pressures and fears of political backlash against repeal reinforce one another, increasing the fiscal burden subsidies impose and dramatically raising the political cost of program exit. In this sense, consumer subsidy programs come to form "policy traps" - initially modest policies that quickly grow and become entrenched, thereby greatly reducing politicians' maneuvering room. We utilize this framework to analyze the meteoric growth and entrenchment of utility subsidies in post-crisis Argentina. In Argentina, subsidies grew
\end{abstract}

Post thanks Tara Buss, Lindsay Mayka, and Christopher Chambers-Ju for excellent research assistance. We are grateful to Sabrina Ayub, Alejandro Boggiano, Antonella Bonacina, Gonzalo Bravo, Diego Cabot, Walter Cont, Mariana Marchionni, Adriana Najuk, Héctor Palomino, Tomás Serebrisky, Santiago Urbiztondo, and Enrique Zuleta Puceiro for advice and data. We also thank participants in U.C. Berkeley's Comparative Politics, Latin American Politics, and Global Metropolitan Studies workshops, in the SAAP conference, and the UTDT workshop, Julián Bertranou, Alejandro Bonvecchi, Ernesto Calvo, Pradeep Chhibber, David Collier, Ruth Berins Collier, Tulia Falleti, Hernán Flom, Eugenia Giraudy, Steve Levitsky, Jonah Levy, Katerina Linos, Andrés Malamud, Stanislav Markus, Aila Matanock, María Victoria Murillo, Paul Pierson, Neal Richardson, Andrés Schipani, Ben Ross Schneider, Valeria Serafinoff, Juan Carlos Torre, Steve Vogel, Nick Ziegler, three anonymous reviewers, and members of the SCID Editorial collective for suggestions and comments. Bril-Mascarenhas acknowledges the support of the Center for Latin American Studies and Post the support of the Committee on Research, U.C. Berkeley.

T. Bril-Mascarenhas $(\bowtie) \cdot$ A. E. Post

Charles and Louise Travers Department of Political Science, University of California, Berkeley,

210 Barrows Hall, Berkeley, CA 94720-1950, USA

e-mail: tombril@berkeley.edu

A. E. Post

e-mail: aepost@berkeley.edu 
despite the private provision of subsidized services - making it difficult for the government to claim credit — even in sectors with weakly organized interests.

Keywords Consumer subsidies · Public utilities · Urban bias · Argentina - Regulation · Welfare state

Many developing countries devote large fractions of government expenditures to broad-based consumer subsidies, or government expenditures that lower domestic consumer prices for key household goods and services. Outlays for consumer fuel subsidies alone often approach, and at times exceed, expenditures on health and education (Table 1). Not only fuel exporting nations like Iran and Turkmenistan but also fuel importers, such as Thailand and Bangladesh, spend more than $2 \%$ of national income on fuel subsidies. These tendencies are visible in democracies like India and El Salvador, as well as autocracies like Vietnam and Azerbaijan. Consumer subsidy regimes have also survived important regime transitions, international financial institution (IFI) pressure to dismantle programs, and partial privatization of the firms providing services at subsidized prices, as in the Ukraine.

Despite their prevalence and persistence, political scientists have largely ignored broad-based consumer subsidy programs. ${ }^{1}$ The nascent literature on the welfare state in the developing world (e.g., Haggard and Kaufman 2008; Huber et al. 2008; Rudra 2002; Segura-Ubiergo 2007) typically does not discuss them. This neglect is striking because consumer subsidies comprise important sources of social protection in developing countries, where households devote large fractions of their income to basic services and foodstuffs. This has left the study of consumer subsidies to economists, whose analyses of program incidence stress that the middle class, rather than the poor, benefit disproportionately from subsidy programs. ${ }^{2}$ If fiscal resources were instead devoted to primary education or basic health programs for the poor, economists argue, these outlays would contribute more directly to human and economic development. Economists' analyses, however, do little to explain the political logic behind the growth and resilience of consumer subsidy programs.

This paper offers a set of propositions regarding the circumstances under which consumer subsidy programs are likely to grow and become rapidly entrenched. These propositions lead us to conceptualize consumer subsidy programs as "policy traps": initially modest programs that grow rapidly and become entrenched quickly, thereby greatly reducing the maneuvering room of political incumbents. We argue that governments are likely to adopt and subsequently increase outlays for consumer subsidy programs when the prices of key inputs, such as imported fuel or domestic labor, rise rapidly. Such rapid price increases are more likely to occur in the developing world, where levels of price volatility, and especially inflation, are generally higher. Wary of popular backlash at the ballot box or in the streets, politicians facing political uncertainty have strong incentives to leave programs in place. This is true even as programs become increasingly costly and when consumers are unaware of the size of the benefits

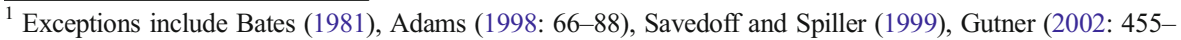
476), and Victor (2009), which explore the dynamics of price controls and subsidy programs in particular sectors, countries, and regions.

${ }^{2}$ E.g., World Bank (2005), Alderman (2002).
} 
they are receiving. Over time, rapid price level changes and concerns about avoiding blame for repealing a program benefitting the majority of the population can reinforce one another, together greatly increasing government expenditures on subsidies. Once programs become entrenched, we expect that governments will tend to repeal subsidy programs only when facing major fiscal constraints or external pressure, and/or few threats to their hold on power. We expect these propositions to have explanatory power among developing countries with different stocks of natural resource wealth, and with either democratic or authoritarian regimes. ${ }^{3}$

These propositions build upon, yet offer important departures from, the literature on the welfare state. While the welfare state literature highlights the importance of slowmoving, long-run changes in prices and demographics, we argue that short-run price volatility is a more important driver of consumer subsidy program growth. The welfare state literature has also shown that politicians have strong incentives to expand and retain programs that are visible and appreciated by important beneficiary groups. In contrast, we argue that in the case of many consumer subsidy programs, politicians also have incentives to defend lower visibility programs for which it is comparatively difficult to claim credit with voters and which in many cases are not championed by concentrated beneficiary groups.

We provide an illustration of the explanatory power of these propositions through an examination of consumer subsidy programs for natural gas distribution and urban bus transport in Argentina following its 2001-2002 economic and political crisis. Argentina is a low-likelihood case for rapid subsidy program growth for a number of reasons. First, state finances did not depend primarily upon natural resource rents, so the government would have faced less popular pressure to share resource wealth via subsidy programs than in countries financed primarily by resource revenue. Second, the country privatized many utilities, meaning that it would be more difficult for the government to claim credit for subsidized prices. Third, Presidents Néstor and Cristina Kirchner were relatively secure politically starting with their victory in the 2005 midterm election, meaning that they had less reason to be concerned about the political consequence of subsidy repeal than leaders in many other countries. Yet in spite of these factors, by 2010, national government expenditures to subsidize consumer prices for basic services such as gas, electricity, and transport had skyrocketed to US\$7.5 billion, or $10 \%$ of the budget, ${ }^{4}$ despite the fact subsidies were largely invisible to their primary beneficiaries for most of the post-crisis period. ${ }^{5}$

Our research design combines a sectoral comparison and process tracing within each sector. Our sectoral comparison allows us to consider a prime alternative explanation of program entrenchment from the welfare state literature, which builds on Olson's theory of collective action: that pressure from concentrated interests, such as unions and firms,

\footnotetext{
${ }^{3}$ In resource-rich countries, where regimes face additional popular pressure to share windfall profits with households, we would expect more substantial consumer subsidies.

${ }^{4}$ Data from Asociación Argentina de Presupuesto y Administración Financiera Pública (ASAP).

${ }^{5}$ Prior to 2009, the private companies that provided these services issued bills that did not mention the government subsidies that allowed firms to keep prices frozen despite inflation. After this date, gas bills and bus tickets noted that consumer prices were subsidized. These changes did not greatly increase subsidy visibility, however, because the portion of the consumer price that was subsidized was not mentioned on transport tickets and buried among other line items in natural gas bills. Moreover, President Cristina Kirchner - who has tended to market her policies directly to the public through the mass media — never made the consumer subsidy program a focus in public appearances.
} 
are key drivers of program expansion and resilience. Our comparison of gas and transport subsidies shows that while interest group pressure can contribute to subsidy program growth, the primary drivers of program expansion and entrenchment are price volatility and fears of political backlash by consumers. Process tracing within each case allows us to assess whether the drivers we cite as important-price level shifts and politicians' concerns with avoiding blame for repeal — indeed explain growth in these two sectors.

\section{Consumer Subsidy Programs as Policy Traps}

Consumer subsidies are budgetary transfers to government agencies or to private firms providing products or services to the general population intended to lower consumer prices. ${ }^{6}$ In their aim of making basic goods more affordable, they differ from producer subsidies, which are government expenditures designed to foment domestic production. ${ }^{7}$ Once adopted, consumer subsidy programs appear to exhibit common features thereafter: growth and persistence. Table 1 reports expenditures on consumer fuel subsidies, the one type for which comparable, cross-national data exist. This table highlights the endurance of these programs even following IMF and privatization programs of the last decades. How can we explain this phenomenon?

Political leaders in the developing world have strong incentives to adopt broad-based consumer subsidy programs following negative and positive price shocks because they provide means to solidify their hold on power. Consumer subsidy programs allow governments to shield the population from sudden changes in the price of food, gasoline, electricity, and other essentials when price shocks would otherwise trigger significant increases in the cost of basic goods and services, as the "urban bias" literature suggests (Bates 1981: 30-3). ${ }^{8}$ In the absence of such programs, sudden price increases for such staples would have large impacts on household budgets in countries with low per capita incomes. Such rapid price hikes could thus be potentially destabilizing for either democratic or authoritarian regimes if they spark large protests in major urban centers (Bates 1981: 31). In resource-rich states, sudden increases in the prices of key export commodities provide political incumbents with an additional opportunity to solidify their hold on power: windfall profits can be distributed through

\footnotetext{
${ }^{6}$ For goods that are traded internationally, standard measures of consumer subsidies refer to the difference between international and domestic prices, and usually adjust for domestic trade and transportation costs (Coady et al. 2006). Consumer subsidies for public services take the form of government expenditures allowing providers to offer services at prices that do not allow them to recoup investment and operational costs.

${ }^{7}$ Two examples from the electricity sector illustrate the difference between consumer and producer subsidies. Governments could lower residential electricity prices through a consumer subsidy program granting electricity distributors a certain subsidy for each kilowatt hour sold to residential customers. Governments could instead encourage investments in alternative energy production by granting electricity distributors a producer subsidy to partially cover the purchase of electricity from generators using solar or wind power.

${ }^{8}$ This logic is consistent with a tradition of scholarship in comparative political economy suggesting that governments have incentives to shield citizens from the risks and market dislocations associated with economic openness through social policy (e.g. Katzenstein 1985; Garrett 1998). While Rudra (2002) and Kaufman and Segura-Ubiergo (2001) conclude, respectively, that data for less-developed countries and for Latin America does not support this "compensation hypothesis," their analyses are based on social security expenditures (as well as healthcare and education, in the latter article), and thus do not include consumer subsidies in their operationalization of welfare spending.
} 
Table 1 Consumer fuel subsidies vs. health and education expenditures in selected low- and middle-income countries

\begin{tabular}{|c|c|c|c|c|c|}
\hline \multirow[t]{2}{*}{ Country } & \multicolumn{2}{|c|}{ Natural resource wealth } & \multirow{2}{*}{$\begin{array}{l}\text { Fuel subsidies as } \\
\text { percentage of } \\
\text { GDP }(2010)^{c}\end{array}$} & \multirow{2}{*}{$\begin{array}{l}\text { Public health } \\
\text { expenditures as } \\
\text { percentage of } \mathrm{GDP}^{\mathrm{d}}\end{array}$} & \multirow{2}{*}{$\begin{array}{l}\text { Education } \\
\text { expenditures as } \\
\text { percentage of } \\
\text { GDP }^{\mathrm{d}}\end{array}$} \\
\hline & $\begin{array}{l}\text { Oil exports as } \\
\text { percentage of } \\
\text { GDP }(2010)^{\mathrm{a}}\end{array}$ & $\begin{array}{l}\text { Net gas } \\
\text { exporter? }^{\text {b }}\end{array}$ & & & \\
\hline Angola & 54.9 & & 1.3 & $4.1(2009)$ & $2.6(2006)$ \\
\hline Iraq & 52.0 & & 13.8 & $2.8(2009)$ & N/A \\
\hline Algeria & 36.6 & Yes & 6.6 & $5.0(2009)$ & $4.3(2008)$ \\
\hline Nigeria & 26.4 & Yes & 1.3 & $2.1(2009)$ & N/A \\
\hline Kazakhstan & 26.0 & Yes & 3.1 & 2.7 (2009) & $2.8(2007)$ \\
\hline Venezuela & 20.9 & & 6.9 & $2.4(2009)$ & 3.7 (2007) \\
\hline Iran & 19.7 & Yes & 22.6 & $2.1(2009)$ & 4.7 (2009) \\
\hline Russia & 13.9 & Yes & 2.7 & $3.5(2009)$ & $4.1(2008)$ \\
\hline Turkmenistan & 13.8 & Yes & 19.3 & $1.2(2009)$ & N/A \\
\hline Ecuador & 9.6 & & 6.4 & $3.0(2009)$ & $1.0(2001)$ \\
\hline Colombia & 5.2 & Yes & 0.2 & $5.0(2008)$ & $4.6(2009)$ \\
\hline Malaysia & 2.2 & Yes & 2.4 & $2.2(2009)$ & $4.1(2008)$ \\
\hline Egypt & 1.3 & Yes & 9.3 & $2.1(2009)$ & $3.8(2008)$ \\
\hline Mexico & 1.2 & & 0.9 & $3.1(2009)$ & 4.8 (2007) \\
\hline Argentina & 0.5 & & 1.8 & $6.3(2009)$ & $5.4(2008)$ \\
\hline Uzbekistan & 0 & Yes & 30.5 & $2.5(2009)$ & N/A \\
\hline Indonesia & -1.2 & Yes & 2.3 & $1.2(2009)$ & $2.5(2005)$ \\
\hline Vietnam & -1.8 & & 2.8 & $2.8(2009)$ & $5.3(2008)$ \\
\hline China & -2.4 & & 0.4 & $2.0(2008)$ & N/A \\
\hline India & -2.9 & & 1.4 & 1.4 (2009) & $3.1(2006)$ \\
\hline South Africa & -3.1 & & 0.6 & 3.4 (2009) & $5.4(2008)$ \\
\hline Philippines & -4.3 & & 0.6 & $1.3(2009)$ & $2.8(2008)$ \\
\hline Pakistan & -5.2 & & 4.2 & 0.9 (2009) & 2.7 (2009) \\
\hline Sri Lanka & -5.5 & & 1 & $1.8(2009)$ & $4.8(2008)$ \\
\hline Ukraine & -5.6 & & 5.6 & 3.8 (2009) & $5.3(2006)$ \\
\hline El Salvador & -6.6 & & 5.5 & 3.9 (2009) & $3.6(2008)$ \\
\hline Thailand & -9.8 & & 2.7 & 3.3 (2009) & N/A \\
\hline Azerbaijan & N/A & Yes & 1.5 & 1.4 (2009) & 2.8 (2009) \\
\hline Bangladesh & N/A & & 4.8 & $1.1(2009)$ & 2.4 (2009) \\
\hline
\end{tabular}

Includes all low- and middle-income countries for which data is available

${ }^{a}$ Calculated from IMF World Economic Outlook Database, accessed December 2011

b 2010 (IEA Natural Gas Information Statistics, accessed June 2012)

${ }^{\mathrm{c}}$ International Energy Agency (includes oil, gas, coal, and electricity). Subsidies are measured by a price gap approach. End consumer prices are compared to a reference price based on prices that would prevail in a competitive market

${ }^{\mathrm{d}}$ World Development Indicators 
broad-based consumer subsidy programs and thereby contribute to citizens' economic well-being and thus contentment with the regime (e.g., Chaudhry 1997: 22, 147-155; Jones Luong and Weinthal 2010: 60; Victor 2009: 20, 22). In both cases, consumer subsidy programs - or the size of subsidies - need not be visible to consumers to have these political impacts.

Consumer subsidy programs adopted in response to price shocks tend to target residents of major metropolitan areas, regardless of leaders' primary support base, for two reasons. First, following major shocks or crises, preserving order in major urban centers signals that regimes are maintaining their hold on power. Meanwhile, even if programs are universalistic in design, the state's ability to ensure that goods and services are delivered at subsidized prices will be higher in urban areas, where state capacity tends to be higher, and - in the case of utilities - where physical delivery networks actually exist (Adams 1998: 68; Bienen and Gersovitz 1986: 28; Lipton 1977: 294). While governments could, in theory, implement targeted subsidy schemes that would do a better job of reaching the rural and urban poor, such schemes are very difficult to roll out quickly following shocks (Victor 2009: 17). ${ }^{9}$

While consumer subsidy programs should be considered part of the welfare state in developing countries because of the significance of these programs for recipients, standard welfare state explanations of program growth and entrenchment only partially elucidate the durability of consumer subsidy regimes due to key differences between the policy areas. First, the primary beneficiaries of consumer subsidies are atomized consumers rather than organized interests. Second, while the monetary value of traditional welfare state benefits such as pensions or workers' compensation are visible to recipients and "traceable" to the government because of the cash payments they receive, the size of benefits from consumer subsidy programs is often less clear to consumers. Nor are benefits clearly traceable to the government, especially when the private sector provides the goods or services in question. ${ }^{10}$ Third, outlays for consumer subsidies are highly sensitive to significant price volatility in key inputs such as imported fuel and food. The prices of inputs for social insurance and health service, in contrast, are not as volatile. These differences lead us to emphasize different drivers of program growth and entrenchment than much of the welfare state literature. In particular, we examine price shocks and politicians' incentives to proactively avoid blame for cutting programs about which consumers have little knowledge. Together, these factors ensure that consumer subsidy programs often constitute policy traps that quickly reduce the maneuvering room of incumbent politicians or successor administrations. We next analyze each of these two mechanisms driving program entrenchment.

\footnotetext{
${ }^{9}$ The implication of this argument is that many types of government - not just those headed by Left parties, which we would expect to be concerned with workers' plights and amenable to market intervention-would have strong incentives to introduce broad-based consumer subsidy programs out of concerns for their political survival.

${ }^{10}$ See Arnold (1990: 47-50) on the traceability of different types of policies. Our argument builds on Mettler (2011), who shows that the majority of citizens receiving welfare state benefits only through the tax code or subsidized services from private companies (such as subsidized student loans) do not realize they are benefiting from government programs.
} 


\section{Price Volatility and Policy Drift}

The welfare state literature helpfully acknowledges that environmental pressures exogenous to programs themselves, such as slow-moving demographic shifts and inflation, can also gradually change the scope of welfare state programs. In the USA and Europe, for example, pension expenditures have gradually risen as the baby boomer generation has begun to collect benefits (Pampel and Williamson 1989: 165-6). Scholars also argue that the steady rates of inflation experienced in industrialized nations have gradually eroded the real value of benefits when payments are not indexed (e.g., Weaver 1988: 186; Pierson 1996: 164; Kemp 2007: 277). Hacker refers to the gradual transformation in scope of policies created by failures to adjust policies to changing environmental circumstances as "policy drift" (2004, 2005).

Yet while Hacker employs "policy drift" to describe a process by which programs are gradually eroded, in the case of consumer subsidies, price shocks can trigger rapid growth in program outlays. When programs are designed to shield consumers from volatility in the prices of products or services, such as food or energy, the cost of shielding consumers from these dramatic changes in input or purchase costs can quickly increase program expenditures. As the price of subsidized goods decreases relative to unsubsidized goods, households will in turn have incentives to increase their consumption of subsidized goods - again raising the government's costs.

\section{Benefit Visibility, Blame Avoidance, and Program Entrenchment}

The welfare state literature also only takes us partway towards understanding program entrenchment. Traditional explanations of welfare state growth and entrenchment stress the pivotal role played by concentrated beneficiary groups. They also emphasize policy feedback mechanisms that assume that both the existence and value of benefits are clearly visible to beneficiaries and traceable to the government. The conventional explanation of welfare state growth, the "power resources" approach, attributes program expansion to worker electoral and associational mobilization and left-leaning governments (e.g., Korpi 1983; Huber et al. 1993). In recent years, scholars have emphasized the importance of policy feedback effects following program adoption: programs create their beneficiaries, who in turn lobby for program continuation or expansion. ${ }^{11}$ Pierson $(1995,1996)$, for example, stresses that welfare state programs create concentrated beneficiary groups with interests to, and often the ability to, defend programs from retrenchment. Huber and Stephens (2001: 10, 28-31) argue that welfare state policies shift voter preferences in favor of new benefits via a "policy ratchet effect." In their analysis, the establishment of welfare state policies engenders higher levels of public support for such policies, which in turn influences subsequent policymaking. Related research stresses that welfare state policies can also promote feelings of political engagement and provide recipients with resources, both of which can increase beneficiary mobilization in defense of existing politics (Campbell 2003, 2012; Mettler 2005). These explanations, which stress how direct program beneficiaries can contribute to program growth and entrenchment, assume that beneficiaries recognize and value the benefits they are receiving.

${ }^{11}$ Campbell (2012) reviews this literature. 
Yet while welfare state benefits such as pensions or workers' compensation are visible to direct beneficiaries because of the cash payments they receive, the monetary value of benefits from consumer subsidy programs is often less clear to consumers. ${ }^{12}$ While programs that provide citizens with ration cards - as is the case for some food subsidy programs - clearly convey the existence and size of the governmental benefit received, many consumer subsidy program designs are far less transparent. Fuel and energy subsidy programs, for example, are typically administered as price stabilization funds under which domestic distributors are compensated for the difference between mandated consumer prices and actual costs. ${ }^{13}$ Unless politicians actively publicize the extent to which the government is subsidizing prices under such a scheme, only a small set of informed citizens will know the difference between production costs or international fuel prices and prices at the pump, and thus understand the size of their benefit. This means that citizens are unlikely to fully appreciate the value of the subsidy they are receiving, or to realize that they have a common interest with other consumers in the expansion or maintenance of benefits. Moreover, consumers are typically unorganized, suffering from the standard barriers to collective action: large group size and small expected benefits from mobilization. So while mobilization by concentrated beneficiaries may explain welfare state stability, consumer mobilization is unlikely to explain the growth and entrenchment of most consumer subsidy regimes due to the relative invisibility of consumer subsidies and consumers' lower levels of organization. ${ }^{14}$ (The standard welfare state logic will apply, however, in cases where consumer subsides are highly visible.)

Recent scholarship on the welfare state and older work on food subsidy programs points to another factor that could drive program growth and entrenchment: lobbying by second-order beneficiaries. Analyzing "hidden welfare state" programs such as the US mortgage interest deduction that voters tend not to attribute to the government, Mettler finds that second-order beneficiaries, such as industry groups, are the primary

\footnotetext{
${ }^{12}$ American politics scholarship suggests that citizens are more likely to understand their self-interest with respect to policies when the consequences are visible, tangible, large, and certain (Citrin and Green 1990: 17), conditions that are not fully met under most consumer subsidy schemes. Mettler (2011) makes a similar argument regarding the relative invisibility of welfare state benefits provided through the tax code or through subsidies for benefits delivered by private companies in the American context. Her survey data suggests that the majority of Americans do not understand they are benefiting from public programs, when in fact they are (Metter 2011: 37).

${ }^{13}$ See IMF (2013) for a description of fuel programs following this model. Citizens are more likely to assume that fuel is subsidized when countries are fuel exporters, as citizens will expect governments to redistribute resource rents, as the resource curse literature suggests.

${ }^{14}$ A recent literature on Latin America (prominently Rhodes 2006; Baker 2009; Echegaray forthcoming) has argued convincingly that scholars should devote more attention to consumers' political attitudes and behavior. The findings from this strand of research suggest that pure Olsonian logic does not always apply and that the new consumer activism and heightened consumer consciousness following market reforms in the region can give consumers veto power. Consumers have organized bill nonpayment campaigns (Rhodes 2006), moderated the agenda of Left leaders (Baker 2009), and boycotted corporations that affect public goods (Echegaray forthcoming). In these accounts, however, consumers are reactive: citizens come to disapprove of privatization (Baker 2009) or protest via nonpayment campaigns or court cases (Rhodes 2006) following highly salient rate increases (Rhodes 2006: 5, 84-90) ex post. Attitudinal change and organization, in other words, come after visible price hikes. Moreover, even in Rhodes's account, consumer associations are not as encompassing and strong as the pensioner and union organizations described in the welfare state literature. While a concern for consumer reactions may accentuate politician concerns about cutting subsidies, then, there is no reason to expect consumer mobilization to be a primary driver of program growth.
} 
defenders of such programs in the USA (Mettler 2011: 32-36, 38). The small body of scholarship on the political economy of food subsidy programs highlights similar dynamics. Bates (1981) maintains that industries benefiting from cheap urban labor helped sustain food subsidy programs in Africa, while Adams (1998: 66-88) argues that middlemen operating the black market in food are responsible for the durability of programs in Bangladesh.

While second-order beneficiaries no doubt contribute to subsidy growth and entrenchment, we argue that a different factor is likely to be of primary importance: politicians' concerns to avoid blame for cutting subsidies enjoyed by the masses. ${ }^{15}$ While consumers may not realize the extent to which the government is subsidizing goods and services before prices are raised and the subsidies financing them are cut, the act of raising prices and removing subsidies alerts them to the size of the benefits they are losing. ${ }^{16}$ As scholars have noted, citizens are often more sensitive to losses than gains (Kahneman and Tversky 1979; Pierson 1996: 145-6; Weaver 1986; Weyland 1996). While consumer groups may not be well organized when politicians are considering retrenchment, the potential for voter mobilization rather than mobilization itself is often sufficient for politicians to fear their reactions (Pierson 1996: 151). This is particularly likely to be the case when politician time horizons shorten because of perceptions of political insecurity. ${ }^{17}$ Such feelings of insecurity are common in the developing countries that typically adopt consumer subsidy programs, because their high levels of economic volatility make governance especially challenging. ${ }^{18}$

The fact that consumer subsidies are often enjoyed disproportionately by urbanites makes leaders facing political uncertainty particularly loath to cut programs. Both democratic and authoritarian governments want to avoid angering the urban masses, as they are more likely than the highly dispersed rural population to launch protests against price increases (Bienen and Gersovitz 1986). To name a few examples, recent attempts to cut relatively low visibility fuel subsidy programs - in which government price stabilization programs at least partially compensated distributors for the difference between mandated consumers prices and fuel costs-have been retracted following major urban protests in countries such as Indonesia (1997, 2003), Jordan (2000), and Mauritania (2008). ${ }^{19}$ Riots and demonstrations in urban centers against price increases, after all, are highly visible and have even precipitated the downfall of some governments (Bates 1981: 31; Bienen and Gersovitz 1986: 40-41; IMF 2013: 21). Rational

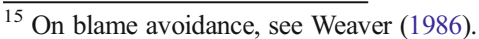

${ }^{16}$ At the time when subsidies are cut, then, citizen attitudes may swing in ways similar to the citizen responses to price hikes instituted by the privatized utilities observed by Baker (2009).

17 Studies of utilities regulation in weak institutional environments have found that politicians tend not to increase consumer rates during politically competitive periods to avoid blame (Murillo 2009; Post 2014a, b). ${ }^{18}$ On economic volatility in developing countries, see Acemoglu et al. (2003) and Wibbels (2006). Relatedly, raising prices for basic consumer goods and services could stoke domestic rates of inflation and/or stymie economic growth by depressing consumption. This provides further incentives to depress consumer prices.

${ }^{19}$ Indonesia has a long-standing fuel subsidy program, originally instated while the country was still an oil exporter. Attempts to repeal subsidies in 1997 led to street protests and contributed to Suharto's downfall (IMF 2013: 21). Protests against efforts to scale back fuel subsidies in 2003, the year before the country became a net fuel importer, also prompted the government to repeal reforms (IMF 2013: 21-2). Jordan, a fuel importer, also backtracked on fuel subsidy cuts in 2000 following large-scale protests (UNDP 2012: 51). Mauritania, also an oil importer, cut fuel subsidies in 2008, triggering protests significant enough to precipitate a military coup; following the coup, subsidies were reinstated (IMF 2013: 30-1).
} 
politicians, in light of such examples, have incentives to avoid irking urban consumers during periods of political competition or instability, even when the urban masses do not represent their core constituencies. Blame avoidance therefore provides leaders with a sufficient reason to keep subsidy regimes in place, even in the absence of strong lobbying efforts by direct or second-order beneficiaries.

Over time, the growing fiscal cost of subsidies and the political disincentives to reduce or repeal them reinforce one another; as the gap between the "real," or unsubsidized, price of goods or services and subsidized prices grows, the political cost of adjustment grows as well. Price hikes of $100 \%$, after all, are more visible and controversial than hikes of $20 \%$. While political leaders could, hypothetically, gradually raise prices and thereby scale back the funding for subsidized pricing programs, there are short-run incentives to put off small adjustments. Why risk death "by a thousand cuts" when one could cut programs in one fell swoop at a later date, or even push the responsibility off to future administrations? The result is a policy trap that incumbent leaders will only exit when faced by dramatically tightening fiscal conditions or external pressures, and/or when they feel particularly secure. ${ }^{20}$ The irony, of course, is that politicians can find their ability to spend in accordance with their political and policy priorities increasingly circumscribed by a policy for which they gain few plaudits from consumers.

\section{The Growth and Entrenchment of Broad-Based Utility Subsidies in Argentina, 2003-2011}

Our analysis of the Argentine case focuses on natural gas distribution and urban bus transport, the most common mode of transportation in the developing world. We illustrate the plausibility of our argument, as well as the failure of the powerresources approach to explain subsidy growth and entrenchment in these cases, through process tracing within each sector. ${ }^{21}$ A structured comparison between the two sectors then allows us to examine the support for alternative explanations that would attribute program growth and entrenchment primarily to concentrated interests such as unions and firms. The empirical analysis we present brings together previously unpublished data conveying the scale, growth, and distributional incidence of Argentina's utility subsidy program. It also draws on interviews with the primary decision-makers in both sectors. $^{22}$

\section{The Trigger: Argentina's 2001-2002 Economic Crisis}

Argentina experienced an economic collapse in 2001 and 2002, subjecting the population to a major income shock. The country's GDP shrank by $11 \%$ within a year. Unemployment increased from 16.5 to $21.5 \%$ and the percentage of people below the

\footnotetext{
${ }^{20}$ With respect to the welfare state, Pierson argues repeal is more likely under conditions of electoral slack (Pierson 1996: 176). Chaudhry (1997: 35) notes that politicians are most likely to repeal consumer subsidies when fiscal conditions tighten.

${ }^{21}$ On the analytic advantages of within-case qualitative analysis, see Collier et al. (2010: 10); Bennett (2010: 207-8).

${ }^{22}$ Most materials cited in this section are archived at the Qualitative Data Repository (https://qdr.syr.edu).
} 
poverty line grew from 38 to $58 \%$ over the same period. A $200 \%$ currency devaluation and $41 \%$ inflation in 2002 significantly reduced the purchasing power of the vast majority of the population, forcing households to spend larger fractions of their income on basic services. Households in the lowest income quintile came to devote $15 \%$ of their expenditures to water and sanitation, electricity, natural gas, and bus transportation (Marchionni et al. 2008a: 42; Marchionni et al. 2008b: 27).

Argentina's political leaders faced strong electoral incentives to mitigate the effect of the crisis on voters. Eduardo Duhalde, president for the 17 months immediately following the crisis, focused his energies on stabilizing the economy and bringing order to the streets. As a part of these efforts, he immediately opened all utilities concession contracts for renegotiation, unilaterally freezing the rates charged to consumers at pre-crisis (and devalued) levels (Law 25561, Decree 50/02). Public opinion supported the president's rate freeze. In 2003, $68 \%$ of households opposed raising the rates charged to residential consumers as a means of compensating companies for dramatic shifts in their cost structure due to the 2002 devaluation (OPSM 2003: 13).

Néstor Kirchner, Duhalde's hand-picked successor, assumed the presidency in May 2003 having won just $22 \%$ of the national vote due to a split in the Peronist party. Concerned about his weak position, Kirchner expanded what had previously been limited subsidy programs designed to help utilities cope with the rate freeze in an inflationary environment. He also chose to maintain rate freezes for all consumers, rather than contain costs by limiting benefits to low income households, as Duhalde's administration had contemplated. These decisions not only differentiated Kirchner's policies from those enacted by Duhalde but also from neoliberal policies of the previous decade.

During the first years of his presidency, the Kirchner administration kept residential gas rates frozen, despite an inflation rate of $51 \%$ for the $2002-2004$ period. ${ }^{23}$ When the price of natural gas rose in 2003, the government decided to ease the burden on distributors by allowing rate increases for non-residential users, thereby making industry cross-subsidize residential consumers. ${ }^{24}$

The Kirchner administration also chose to maintain transport tickets at pre-crisis levels. To help bus operators cope with the rate freeze, the government provided them with approximately AR\$ 316 million in direct subsidies during $2003 .{ }^{25}$ Moreover, the administration reportedly relaxed enforcement of the firms' contractual obligations to purchase new buses. ${ }^{26}$ Failing to subsidize, it was assumed, would have caused bus operators to declare bankruptcy and the transport system to collapse. According to our interlocutors, Kirchner wanted to avoid incurring the wrath of millions of urban commuters.

\section{The Tightening of the Policy Trap: The Meteoric Growth of Argentina's Subsidy} Program Under the Kirchners

Néstor and Cristina Kirchner both chose to maintain rate freezes and the related subsidy programs throughout their administrations (2003-present). Over time, the fiscal burden

\footnotetext{
$\overline{{ }^{23}}$ This decision was not expressed in public out of concern that doing so would further complicate foreign debt renegotiations following the country's 2001 default. However, three interviewees who took part in the negotiations confirmed that Kirchner was personally committed to maintaining the tariff freeze.

${ }^{24}$ Decrees 180 and 181 (2004).

${ }^{25}$ Calculations using data from the CIPPEC, the Secretary of Transportation, and the UCOFIN.

${ }^{26}$ Not-for-attribution interviews, June 2011.
} 
associated with utility subsidies grew dramatically. By 2010, the government devoted approximately AR\$ 30 billion-10\% of the total federal spending - to utility subsidies. ${ }^{27}$ Figure 1 conveys the remarkable growth of subsidies in the gas distribution and urban transport sectors in real terms, which mirror these broader trends.

In line with expectations, two sets of factors contributed to this meteoric growth of federal utility subsidies: strong price pressures and political disincentives to cut the subsidies sustaining price controls. This policy trap became tighter each year as the gap between the frozen prices and the real cost of producing services steadily increased, raising the political costs of repeal.

\section{Price Pressures Fuel Program Growth}

Following the introduction of these subsidy programs in Argentina, price pressures triggered impressive increases in costs. In gas distribution, the fiscal burden of government efforts to maintain frozen consumer prices increased because of shortages in the availability of domestically produced gas (Cordiviola 2010). Néstor Kirchner's administration chose to augment domestic supply through gas imports. In 2004, it created a new state company, ENARSA, which subsidized the difference between the frozen price of gas within Argentina's market and the higher price of the imported gas. By providing private gas distributors with a subsidized input, the government's frozen consumer rates could continue to be viable for providers. The government had put itself in the position of protecting consumers against fluctuations in international gas prices.

Automatically linking subsidy levels to the cost of imported gas, however, triggered increases when the price of gas imports from Bolivia nearly tripled between 2004 and 2010 (ACIGRA 2010). Moreover, shortages of domestically produced gas worsened in 2008, forcing the government to increase the amount of gas purchased at these higher prices. Starting in 2008, the national government supplemented natural gas imports with liquefied natural gas (LNG) imports, for which the per unit cost was six times as expensive as natural gas had been in 2004 (ACIGRA 2010: 11).

An inflationary spiral, which deepened over the course of the decade, increased the prices of key inputs for other types of public services. While the domestic rate of inflation receded from the $41 \%$ rate observed in 2002, it rose to double-digit levels again starting in 2005, and exceeded $20 \%$ in 2008 and $2010 .^{28}$ Rising input costs, in turn, widened the gap between the costs of actually delivering services and revenue at the frozen prices mandated by the government. In the bus sector, inflation prompted workers to demand wage increases. Influential unions managed to obtain a $90 \%$ increase in real wages over the 2003 to 2010 period (Fig. 2). While real wages increased across sectors, the gap between the inflation-adjusted wage of bus drivers and the economy-wide labor income doubled. These increases were difficult to finance because wages comprised around $50 \%$ of the total operating costs. ${ }^{29}$ The government was determined to avoid a collapse in urban transport that would sour public opinion.

\footnotetext{
${ }^{27}$ Calculations based on data from ASAP.

${ }^{28}$ As data from Argentina's national census bureau became unreliable in 2006, the cited inflation data comes from the Santa Fe province statistics agency, which is considered to be politically independent.

${ }^{29}$ As the balance sheets of bus companies are not public we relied on data from three sources: the city of Rosario transport regulatory agency, Transport Secretary Resolution 270/09, and interviews with business and labor representatives.
} 


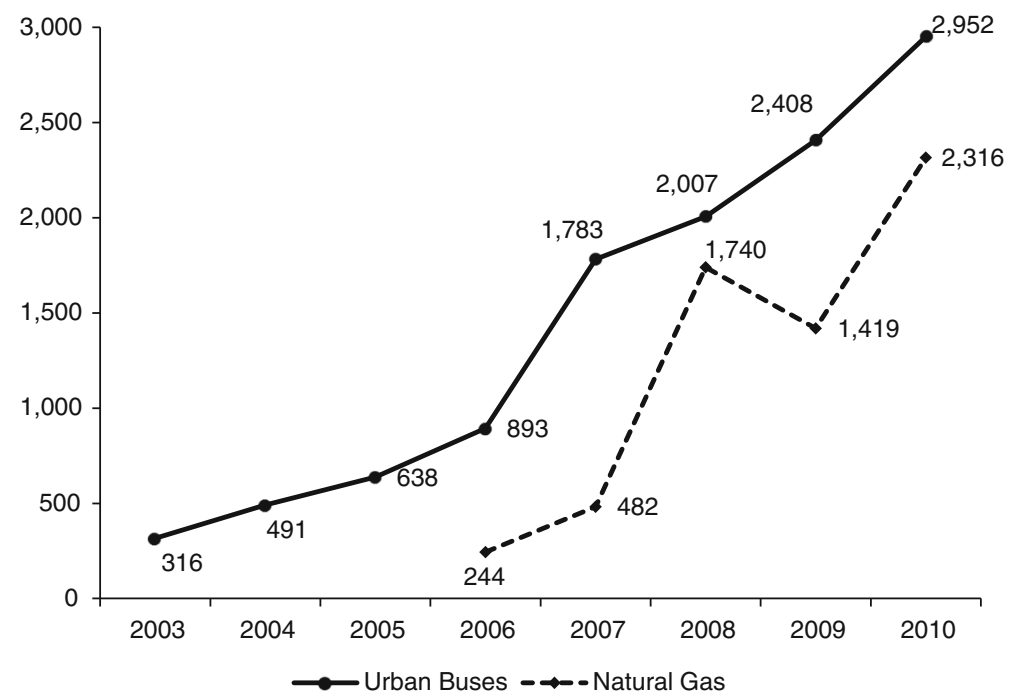

Fig. 1 Federal government subsidies to restrain increases in natural gas tariffs and tickets for urban buses (millions of AR 2003 pesos). Sources, gas: calculations based on data from ASAP. The international prices of natural gas and LNG plummeted in the last quarter of 2008 and remained low for most of 2009, explaining the dip in the gas curve. Bus: calculations using data from the CIPPEC, the Secretary of Transportation, and the UCOFIN

Officials thus chose to subsidize the gap rather than force providers to pay for wage increases on their own. In 2006, they created a program that allocated government resources for this specific goal (Decree 678/06). ${ }^{30}$

\section{Political Disincentives to Repeal}

The Kirchner administrations faced strong disincentives to repeal price freezes and the subsidy programs that supported them, even as the fiscal cost associated with these programs grew dramatically. Scaling back subsidy programs and thus raising consumer rates would most likely turn residents of Greater Buenos Aires (GBA), and thus national public opinion, against the government. Our field research suggests that, enjoying health revenue growth, the Kirchners did not feel this political risk was worth running. As expected, concerns about voter backlash rather than interest group lobbying served as a key driver of program growth and entrenchment.

Argentine public opinion following the crisis was decidedly unsupportive of adjusting the household utility rates to keep pace with inflation, which amounted to $62 \%$ for the $2002-2005$ period. For instance, $72 \%$ of the respondents to a 2006 survey strongly supported the Argentine government's utility rate freeze, despite the fact that the real value of consumer rates had declined significantly (OPSM 2006: 12-3). Approving rate increases that would enable Kirchner to cut subsidies would thus involve large political risks. Subsidy cuts would be felt most in urban areas, and particularly GBA. While the subsidy programs were ostensibly universal, freezes in residential gas rates only benefited households that were connected to the natural gas

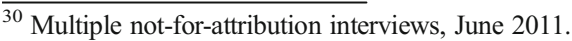




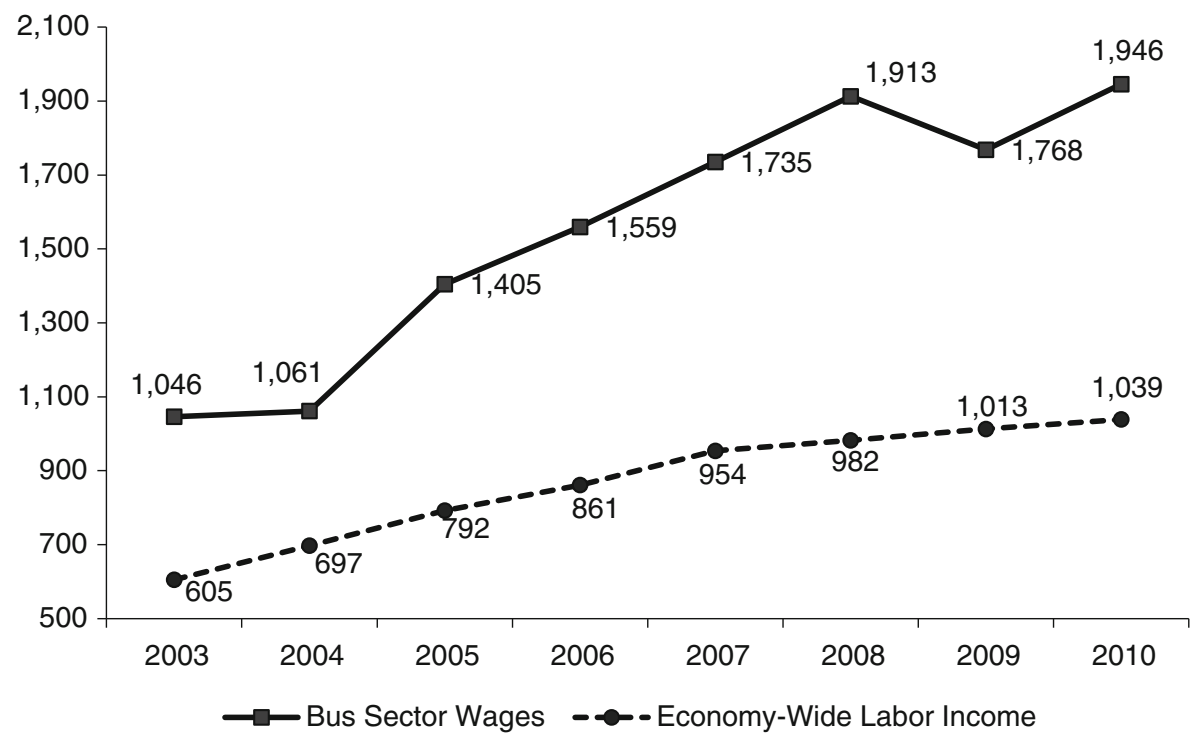

Fig. 2 Monthly wages of urban bus drivers and monthly economy-wide labor income, 2003-2010 (2003 AR pesos). Source: own calculations based on data from the Ministry of Employment, Labor and Social Security, and SEDLAC database (CEDLAS and The World Bank). Each data point represents the average monthly wage of urban bus drivers in December of each year. Economy-wide figures correspond to the final semester of each year

networks, which are far more developed in the GBA than elsewhere in Argentina. In 2001 , the region was home to $43 \%$ of all network insiders but had only $32 \%$ of the national population. Moreover, four relatively poor provinces lie entirely outside the natural gas network (Chaco, Misiones, Corrientes, and Formosa, which together account for $10 \%$ of the country's population). The geographic bias of the rate freeze and initial accompanying subsidy program was also evident in the bus transport sector. In 2003, Buenos Aires received $50 \%$ of total annual bus subsidies, despite possessing only a third of Argentina's population. ${ }^{31}$ As the subsidy program grew in size, it retained its geographic focus on urban areas, and particularly on GBA. Throughout the 2000 s, households living in central, more urbanized parts of the country continued to enjoy greater access to gas networks than those living in more peripheral provinces. ${ }^{32}$ Government subsidies to restrain the price of urban bus tickets added up to at least AR\$ 20.2 billion for the 2003-2010 period, with roughly $70 \%$ of these funds allocated to GBA. ${ }^{33}$ Consequently, bus tickets became significantly more expensive outside GBA:

\footnotetext{
${ }^{31}$ This estimate includes SISTAU transfers for firms in Jurisdicción Nacional and firms in GBA. As the government did not release 2003 transfers disaggregated by firm, we assumed that the proportion of funds received by GBA firms in 2003 was equal to that of $2005-25 \%$ of the total allocations for the province of Buenos Aires. Ministry of the Economy Resolution 84/02 established that the provincial distribution of the SISTAU resources would be based on the number of passengers rather than on population. As a result, in per capita terms, the winner was GBA, the region with the largest passengers/population ratio in Argentina.

${ }^{32}$ We calculated the changes in the number of network insiders and outsiders using micro-data from INDEC for 2003 and 2009. Data is available upon request.

${ }^{33}$ Total funds for SISTAU and complementary compensations programs (calculations based on CIPPEC data). As the diesel subsidy is not included, our estimate of the size of transport subsidies is conservative. Following Marchionni et al. (2008a) and interviews with business representatives, we assume that $97 \%$ of the Jurisdicción Nacional subsidies were distributed among GBA bus companies.
} 
by 2007 , tickets were $88 \%$ more expensive in Córdoba and Santa Fe, the two largest provinces after Buenos Aires (Marchionni et al. 2008a: 51).

While the Kirchners' core constituents were the urban unemployed and blue-collar workers, the residents of GBA more generally were also of great political relevance because they could turn the tide of national public opinion against the Kirchner administrations. Néstor Kirchner was unnerved by the specter of mass public opinion turning against him in the political, economic, and media capital of the country during his first years in office, while he was concerned with consolidating his grip on power. Montenegro, drawing on extensive interviews, writes that Kirchner "was afraid of the reaction that the unfreezing of [utility] rates would produce in the middle-class public opinion in GBA. He would reply to his staff members, who proposed ending the rate freezes and accompanying subsidy programs, by saying, 'we would unfreeze rates if we were able to guarantee that (such a measure) does not make it to the cover of Clarin"" (Montenegro 2011: 198). ${ }^{34}$

Protests against rate increases in provincial capitals undoubtedly reminded the Kirchners of the potential for - and visibility of - public protests against price increases in major urban centers. The governor of Córdoba province faced such a strong political reaction to water rate increases in 2006 that he found it necessary to fire his public works minister (La Nación, February 19 and 24, 2006). Meanwhile, bus ticket price increases in the major cities of Córdoba and Rosario prompted legislative conflict and public demonstrations (El Cronista Comercial, December 17, 2009; La Voz del Interior, November 12, 2010; Rosario/12, August 1, 2008). Néstor Kirchner also worried that cutting the subsidy programs would further stoke inflation, which surveys suggested was one of the three most worrying issues to voters. ${ }^{35}$ By 2011 , economic consultants calculated that an abrupt end to the government's subsidy policy would immediately double the already high rate of inflation, pushing it to an annual rate of $50 \%$ (Clarín, January 27, 2011).

Over the course of the decade, the gap between the "real" and subsidized price of services grew, and as a result, the political cost of adjustment grew as well. By 2011, it was estimated that gas distribution margins would have to be increased by around $150 \%$ to restore some of the profitability that had been shrinking since tariffs were frozen. Similarly, by 2010, business representatives estimated that if the subsidies were to be cut, bus ticket prices would have to rise by over $300 \%$ to allow firms to run their business. ${ }^{36}$ Rate increases of this magnitude would be very visible and likely turn voters against the government. Governments, of course, can choose to cut subsidy schemes incrementally rather than all at once. The Cristina Kirchner administration's tentative efforts to curtail gas subsidies in 2008, however, generated such strong reactions that the government repealed the measure and shied away from similar efforts for over 3 years. ${ }^{37}$

The Argentine experience with broad-based utility subsidies following the 20012002 crisis illuminates how programs can quickly become policy traps. As expected,

\footnotetext{
${ }^{34}$ Buenos Aires-based Clarín is the most important newspaper in Argentina.

${ }^{35}$ Multiple not-for-attribution interviews, June 2011, La Nación, April 26, 2008.

${ }^{36}$ Estimates based on interviews with business representatives from both sectors. For buses, estimates published in the media coincide with interview data: La Nación, October 3, 2010.

${ }^{37}$ In the first winter following the decree that increased gas prices (2009), the consumer organizations, opposition parties, and the federal ombudsman office focused public attention on the rate increase, while media headlines referred to the measure as a tarifazo, or a giant tariff hike.
} 
the key drivers of program growth and entrenchment were concerns regarding voter backlash and price level changes. Néstor and Cristina Kirchner received several proposals from their economic ministers as well as from their energy and transport secretaries to exit broad-based subsidies gradually in order to avoid fiscal strains in the future. ${ }^{38}$ The Kirchners, however, rejected all of these policy proposals, arguing that such a move would entail unnecessary political risk in the context of fiscal abundance.

Gas Distribution and Bus Transport: Absence and Presence of Organized Beneficiaries

The Kirchners consolidated and maintained subsidy programs in both sectors in spite of their rapidly escalating costs. They did so even as they strengthened their hold on power and even though it was difficult for them to claim credit for these expenditures. The following analysis of the factors driving subsidy program growth in the gas distribution and bus transport sectors shows that rising input costs and concerns regarding voter backlash, especially in GBA, was sufficient to fuel subsidy program growth and entrenchment. At the same time, the presence of strong, organized interest groups affected the distribution of the benefits of subsidy programs; as one might expect, workers and firms secured a greater share of program benefits in bus transport, where they were better organized.

\section{Variation in Union Leverage}

Union political leverage has varied significantly across sectors in Argentina. The union in the gas distribution sector, the Federación de la Industria del Gas, is among the weakest within the Argentine labor movement. The federation played a peripheral role within the national labor federation closely aligned with the Kirchners, and it had only weak leverage with employers. In addition, because of the greater capital intensity of the gas industry and the fact that gas distribution firms outsource most activities involving blue collar workers, labor costs constitute a small fraction of provider outlays; in 2007, for instance, the two largest gas distribution companies in Argentina (Metrogas and Gas Natural Ban) reported that labor costs comprised only 5 and $10 \%$ of their respective operating costs. ${ }^{39}$ This means that wage increases do not necessarily depend on subsidy increases. As a result, union representatives did not participate in subsidy negotiations. As subsequent analysis will show, subsidy increases instead stemmed from the government's decision to subsidize fuel imports so as to maintain consumer prices at existing levels.

In contrast, Argentina's bus transport union is well organized, has constituted a core member of the Kirchner coalition, and can credibly threaten to paralyze services. The Unión Tranviarios Automotor (UTA), the union that represents bus transportation workers, historically has exercised an important political role. Néstor Kirchner actively recruited this union to his coalition following his narrow electoral victory in 2003. Moreover, the head of the UTA has been one of the closest allies of Hugo Moyano, who came to head Argentina's major union federation in 2004, further strengthening the UTA's links with the Kirchner administration.

\footnotetext{
${ }^{38}$ Interviews with government, business, and labor representatives in the bus and gas sectors, June 2011. See also Montenegro (2011).

${ }^{39}$ Our calculations based on data from the National Securities Commission. Data for previous years confirm this cross-sector difference.
} 
While the Kirchners chose to devote ever more significant resources to maintaining consumer subsidies in both sectors, bus transport workers, but not gas workers, secured a large fraction of subsidies to their sector. The UTA has managed to push for large increases in federal subsidies for bus transport between 2003 and the present, which have been used to fund wage increases (Fig. 2). Indeed, subsidy increases have typically been negotiated during annual tripartite wage negotiations. Because firms could only afford to grant wage increases if the government increased subsidies, negotiations took place between the union and the Transportation Secretary, who reported directly to President Néstor Kirchner, and later President Cristina Kirchner. ${ }^{40}$ In contrast, gas unions did not have a role in shaping the government's subsidy policy, and wage levels were negotiated directly with employers; this, along with the gas industry's relatively low labor intensity, explains why labor did not become a driver of subsidy growth and why it did not benefit directly from the billions of dollars the government poured into the gas sector.

\section{Variation in Firm Leverage}

Private sector service providers also possessed greater organizational capacity and political leverage in urban transportation than in gas distribution. Nine firms distribute natural gas in Argentina, each of which has a geographic monopoly. While there is an industry association, interviewees suggested it exercises little political power. This organizational weakness has allowed the Kirchner administrations to negotiate directly with individual firms regarding consumer rates and other regulatory issues - a strategy that dilutes corporate leverage. In addition, while domestic firms dominate the bus sector, foreign investors control gas distributors. Foreign investors have threatened to take the government into international arbitration to force the government to the negotiating table following the rate freezes instituted after the 2002 crisis. ${ }^{41}$ This could only have reinforced the Kirchners' proclivity to work with domestic firms, weakening the political leverage of foreign firms.

In contrast, firms in the bus sector possessed greater leverage. The Argentine urban bus industry had undergone a process of concentration in which dozens of bankrupt firms were absorbed by large players. ${ }^{42}$ In the 2000 s, the sector evolved towards a structure with fewer but stronger firms represented by well-institutionalized associations. The two dominant associations, each led by one of the two largest business groups operating bus services, represented firms' interests in subsidy negotiations. ${ }^{43}$ These differences in industry-level organization and preferred negotiating strategies allowed firms in the bus sector to push for a greater share of benefits from a growing subsidy program. In the aftermath of the devaluation, bus operators were open to accepting Kirchner's decision to freeze bus ticket prices as long as they were allowed to postpone required investments to renovate their bus fleet ${ }^{44}$ and received some compensation

\footnotetext{
${ }^{40}$ The negotiation process was described in multiple not-for-attribution interviews, June 2011.

${ }^{41}$ See La Nación, July 28, 2003.

${ }^{42}$ For a journalistic account, see La Nación, July 19, 2011.

${ }^{43}$ In urban bus transportation, the federal government has regulatory authority over the services in the city of Buenos Aires and the jurisdicción nacional (i.e., buses that cross provincial borders, $97 \%$ of which are based in GBA). Therefore, the interlocutors of the national government in this sector are the business associations that represent GBA firms; it is to them that we refer in this analysis.

${ }^{44}$ This decision materialized in the Transport Secretary Resolutions 424/03, 867/04, and 1025/05.
} 
for the increasing price of gasoline. Since 2006, the Kirchners have been particularly receptive to business concerns in the bus sector. While the 20032006 subsidies were almost entirely dedicated to covering the rising labor costs, starting in 2006, the new subsidy allocations were generous enough to allow firms to invest and to restore their profits. Bus operators in GBA purchased seven times more new vehicles between 2008 and 2011 than between 2002 and $2005 .^{45}$

The fiscal costs of gas subsidies still grew rapidly, but gas operators secured fewer gains. Rather than entertaining the possibility of the sorts of investment subsidies received by the bus operators, they demanded rate increases that would allow them to recover pre-devaluation profit margins. Their lobbying efforts bore no fruit; as of 2010, 7 years after the Kirchners took power, residential gas rates remained frozen. ${ }^{46}$ While the government often promised that rates would be raised at some point, the Kirchners have not allowed regulatory agencies to follow through with such promises. Gas subsidies increased dramatically during this period, but they were used entirely to lower the domestic gas price and did not yield economic benefits for distributors.

In summary, comparing the dynamics of subsidy program growth in Argentina's bus transport and gas distribution sectors offers a number of insights. First, a combination of price pressures and blame avoidance together drove program growth in these two, quite different sectors. While concentrated interests helped fuel subsidy program growth in the bus sector, gas subsidies grew in their absence. This suggests that price shocks and concerns to avoid blame for cutting low visibility policies are sufficient to explain program growth and entrenchment. It also underscores the importance of focusing on different drivers of program durability than those stressed in the welfare state literature.

Our analysis also suggests that subsidy program growth in the post-crisis period cannot be attributed to the Kirchners' affiliation with a "left populist party" (Etchemendy and Garay 2011: 283) and strong alliance with organized labor, as a "power resources" approach might predict. While the Kirchners devoted significant funds to a number of flagship social policies targeting core supports, including an impressive expansion of the pension system and income support programs, consumer subsidy programs did not constitute part of the same programmatic thrust. ${ }^{47}$ First, while the Kirchners emphasized their pension program expansion and income support programs during midterm elections and their 2007 and 2011 presidential campaigns, they did not publicize the government's contributions to consumer subsidy schemes until 2009; thereafter, it has still not been discussed as a core element of the Kirchner platform. Second, while the pension expansion and income support programs clearly target core supporters, consumer subsidy programs devoted a significant share of precious resources to opposition voters who were unlikely to swing. The city of Buenos

\footnotetext{
$\overline{45}$ Calculations based on unpublished data from the Secretary of Transportation.

${ }^{46}$ In 2006, GN BAN managed to negotiate a modest increase in residential tariffs, a sole exception to this pattern. Rates remain frozen in de facto terms (Cordiviola 2010: 2; not-for-attribution interviews with three business representatives, January and June 2011).

${ }^{47}$ We thank one of our reviewers for suggesting we compare the Kirchners' consumer subsidy programs with their major social policy initiatives.
} 
Aires was the largest geographical winner of the subsidy programs, ${ }^{48}$ but when compared to the other main electoral districts, its voters were the least supportive of the Kirchner governments throughout the last decade. Moreover, a significant part of the working class was excluded from the gas subsidy program because it did not live within reach of the natural gas distribution networks and was thus instead reliant on LPG cylinders whose price the government failed to effectively control (BrilMascarenhas 2011). Finally, in contrast with the administration's flagship social policies, we found no indication that the Kirchners' core constituents actually pushed for consumer subsidies: the non-unionized working class did not make public utility prices a focus of its demands. While union members in non-utilities sectors benefited from the Kirchners' subsidy scheme as consumers, we found no evidence that unions outside the utilities sector pushed for consumer subsidies in negotiations with the government, which focused on issues that promised larger impacts on workers' wages (see Etchemendy and Collier 2007). Rather, consumer subsidy programs expanded dramatically because of an interaction between the rapid growth in the prices of key inputs and political concerns to avoid blame.

\section{Conclusion: Broad-Based Consumer Subsidies as Policy Traps}

Many developing countries devote large fractions of government budgets to finance broad-based subsidies designed to lower consumer prices for basic goods and services such as food, fuel, and public transportation. This paper suggests that these programs often constitute policy traps - initially affordable policies that quickly become increasingly costly and difficult to repeal. In doing so, they can greatly constrain original program champions or subsequent administrations.

Our paper provides an analytic framework explaining why rational politicians facing political uncertainty would maintain broad-based consumer subsidy programs, despite the propensity of these programs to evolve into policy traps. Price shocks and political disincentives to repeal a program that benefits the majority of the population tend to reinforce one another, together greatly increasing the associated fiscal burden. Once entrenched, politicians will tend to repeal such programs only when facing major fiscal constraints, external pressure, and/or political security.

Argentina's experience with broad-based utility subsidy programs following the 2001-2002 economic crisis suggests that policy traps can take hold even when program benefits are almost invisible to the population, and in the absence of strong interest group pressure. The country's utility subsidy program for consumers came to comprise roughly $10 \%$ of government expenditures, devouring five times as many resources as the government's signature income support program.

\footnotetext{
${ }^{48}$ The city of Buenos Aires, the wealthiest region of the country, has Argentina's second largest electorate after Buenos Aires province. The city is embedded within GBA, the region that benefited most from the subsidy policy. Within the metropolitan area, the city benefited more than other jurisdictions for two reasons. First, it has the densest network of natural gas pipelines (with over $94 \%$ of its households connected to the distribution network in 2009 , compared to $70 \%$ in the conurbation), allowing subsidized prices to reach almost the entire electorate. Second, per capita subsidies in the bus sector were higher in the city than in the surrounding region, as reflected in the fact that bus ticket prices were lower inside the city's boundaries than outside of them.
} 
A brief examination of consumer subsidy programs in other resource-poor countries (Table 1) suggests that the drivers of program growth and entrenchment highlighted by our analytic framework - political uncertainty, price level changes, and blame avoidance - are at work in vastly different contexts. The Ukraine has historically imported natural gas, the main source of household energy (IEA 2006: 65), from Russia. In 2012, Russian imports met two thirds of domestic consumption (Mitra and Atoyan 2012: 5). After the fall of the USSR, Russia decided to gradually stop subsidizing its gas exports to the newly independent republics (Havrylyshyn et al. 1994: 359). Between 2005 and 2009, the price of Russian gas increased every year (Kuzio 2010: 15); a bilateral contract signed in January 2009 immediately increased the price the Ukraine paid by $100 \%$ and mandated quarterly updates to finally raise prices to international market levels. ${ }^{49}$ Similar to ENARSA in Argentina, the Ukrainian state-owned giant Naftogaz enters contracts to purchase natural gas at international prices and then 42 regional gas companies - most of which are partially or totally privatized (IEA 2006: 40, 42) distribute it to residential consumers at prices that cover only $15 \%$ of the price paid for the imported gas (IMF 2010: 11). The national government then finances the difference. In other words, political leaders in this country, marked by political instability and swings between democracy and competitive authoritarianism, have chosen to shield consumers from international price shocks by subsidizing consumer prices extensively (estimated by IEA between 5.2 and $6.7 \%$ of the GDP in the 2009-2011 period). Their actions brought the country to the brink of economic collapse. In 2009, GDP fell by $15 \%$ and the combined general government deficit equaled $8.7 \%$ of GDP (IMF 2010: 9). The government subsequently signed standby agreements with the IMF in 2008 and 2010 that obliged it to raise household gas tariffs to market prices but backtracked on rate hikes on multiple occasions, anticipating political repercussions (Kuzio 2010: 15). 50 The subsidy regime, in other words, had become so entrenched that leaders were willing to paralyze negotiations with the IMF to retain it. ${ }^{51}$

Similar dynamics appear at the subnational level in the Indian electricity sector. Following independence, India's central government delegated electricity distribution to state governments. Until the early 1970 s, low levels of political competition and a lack of rural political mobilization allowed state leaders to promote industrialization by charging residential consumers more than industry (Kale 2004: 471-2). As state political systems became more competitive, however, state politicians pushed electricity boards to subsidize electricity for farmers and residential consumers, the most important voting blocs (Kale 2004: 472; Tongia 2007: 111,126). They failed to raise tariffs fast enough to keep pace with increases in the price of power faced by state distribution boards (Tongia 2007: 128). As a result, the cost of subsidizing the state distribution companies burgeoned by the late 1980s (Kale 2004: 472) and came to be the single largest drain on state finances for many states, greatly reducing their ability to provide other social services (Tongia 2007: 110). Liberalization in the sector during the 1990s only aggravated the problem because contracts with private generating companies increased the average cost of supply (Tongia 2007: 110, 128, 143, 165). Electricity subsidies more than doubled in real terms during the $1990 \mathrm{~s}$, reaching $0.25 \%$ of GDP

\footnotetext{
${ }^{49}$ Global Insight Daily Analysis, January 20, 2009.

${ }^{50}$ Platts Oilgram News, August 27, 2009.

${ }^{51}$ Daily The Pak Banker, July 2, 2013.
} 
by 2010 (Tongia 2007: 131; IEA). Even as the opportunity costs grow larger, politicians have largely refrained from scaling back subsidies out of electoral concerns (Kale 2004: 490). Politicians across the Indian states, in other words, also have found themselves in a policy trap. As input costs have grown, the cost of maintaining subsidized prices has increased. Yet given high levels of state level electoral competition - and thus political uncertainty - there have been strong disincentives to repeal subsidies benefiting important voting blocs.

These case studies suggest that our analytic framework travels easily to other developing and transition economies with a variety of political regime types. We hope that scholars will examine in greater depth the extent to which changes in the main variables we highlight, as well as factors we do not examine explicitly-such as resource wealth - affect the politics of growth and entrenchment in consumer subsidy regimes. We also hope that future scholarship will examine the extent to which our policy trap concept illuminates other policy areas. The concept could, for instance, be potentially applied to a range of empirical phenomena, including the persistence of exchange rate policies or other types of macroeconomic measures. Most importantly, we encourage other scholars to widen our definition of the welfare state in the developing world, and join us in examining the extent to which conventional explanations are adequate for understanding the additional policy areas that come into view.

Open Access This article is distributed under the terms of the Creative Commons Attribution License which permits any use, distribution, and reproduction in any medium, provided the original author(s) and the source are credited.

\section{References}

Acemoglu D, Johnson S, Robinson J, Thaicharoen Y. Institutional causes, macroeconomic symptoms: volatility, crises and growth. Journal of Monetary Economics. 2003;50(1):49-123.

ACIGRA. Políticas de formación de precios del gas natural y su impacto sectorial. Rio de Janeiro; 2010.

Adams RH. The political economy of the food subsidy system in Bangladesh. Journal of Development Studies. 1998;35(1):66-88.

Alderman H. Subsidies as a social safety net: effectiveness and challenges. Washington, DC: World Bank; 2002.

Arnold RD. The logic of congressional action. New Haven: Yale University Press; 1990.

Baker A. The market and the masses in Latin America: policy reform and consumption in liberalizing economies. New York: Cambridge; Cambridge University Press; 2009.

Bates RH. Markets and states in tropical Africa: the political basis of agricultural policies. Berkeley: University of California Press; 1981.

Bennett A. Process tracing and causal inference. In: Brady HE, Collier D, editors. Rethinking social inquiry: diverse tools, shared standards. 2nd ed. Lanham, Md: Rowman \& Littlefield Publishers; 2010. p. 207-19.

Bienen HS, Gersovitz M. Consumer subsidy cuts, violence, and political stability. Comparative Politics. 1986;19(1):25-44.

Bril-Mascarenhas T. The politics of utility subsidies under populism. The case of Argentina, 2003-2010. MA Essay, University of California-Berkeley; 2011.

Campbell AL. How policies make citizens: senior political activism and the American welfare state. Princeton: Princeton University Press; 2003.

Campbell AL. Policy makes mass politics. Annual Review of Political Science. 2012;15(1):333-51.

Chaudhry KA. The price of wealth: economies and institutions in the Middle East. Ithaca, N.Y: Cornell University Press; 1997.

Citrin J, Green D. The self-interest motive in American public opinion. Research in Micropolitics. 1990;3:1-28.

Coady D, El-Said M, Gillingham R, Kpodar K, Medas P, Newhouse D. The magnitude and distribution of fuel subsidies: evidence from Bolivia, Ghana, Jordan, Mali and Sri Lanka. Washington, D.C: International Monetary Fund; 2006. 
Collier D, Brady HE, Seawright J. Introduction to the second edition: a sea change in political methodology. In: Brady HE, Collier D, editors. Rethinking social inquiry: diverse tools, shared standards. 2nd ed. Lanham, Md: Rowman \& Littlefield Publishers; 2010. p. 1-10.

Cordiviola, M. Tarifas de gas natural: Diagnóstico y alternativas de normalización. Buenos Aires; 2010.

Echegaray F. Voting at the marketplace: political consumerism in Latin America. Latin American Research Review. Forthcoming.

Etchemendy S, Collier RB. Down but not out: union resurgence and segmented neocorporatism in Argentina (2003-2007). Politics Society. 2007;35(3):363-401.

Etchemendy S, Garay C. Argentina: left populism in comparative perspective, 2003-2009. In: Levitsky S, Roberts KM, editors. The resurgence of the Latin American left. Baltimore: Johns Hopkins University Press; 2011. p. 283-305.

Garrett G. Partisan politics in the global economy. Cambridge, UK; New York: Cambridge University Press; 1998.

Gutner T. The political economy of food subsidy reform: the case of Egypt. Food Policy. 2002;27(5-6):45576.

Hacker JS. Privatizing risk without privatizing the welfare state: the hidden politics of social policy retrenchment in the United States. American Political Science Review. 2004;98(02):243-60.

Hacker JS. Policy drift: the hidden politics of US welfare state retrenchment. In: Thelen KA, Streeck W, editors. Beyond continuity: institutional change in advanced political economies. Oxford; New York: Oxford University Press; 2005. p. 40-82.

Haggard S, Kaufman RR. Development, democracy, and welfare states: Latin America, East Asia, and Eastern Europe. Princeton: Princeton University Press; 2008.

Havrylyshyn O, Miller M, Perraudin W, Aven P, von Hagen J. Deficits, inflation and the political economy of Ukraine. Economic Policy. 1994;9(19):354 401.

Huber E, Stephens JD. Development and crisis of the welfare state: parties and policies in global markets. Chicago: The University of Chicago Press; 2001.

Huber E, Ragin C, Stephens JD. Social democracy, Christian democracy, constitutional structure, and the welfare state. American Journal of Sociology. 1993;99(3):711-49.

Huber E, Mustillo T, Stephens JD. Politics and social spending in latin America. The Journal of Politics. 2008;70(2):420-36.

IEA. Ukraine energy policy review 2006. Paris: OECD/IEA; 2006.

IMF. Case studies on energy subsidy reform: lessons and implications. 2013.

IMF. IMF Country Report No. 10/262; 2010.

Jones Luong P, Weinthal E. Oil is not a curse: ownership structure and institutions in Soviet successor states. New York: Cambridge University Press; 2010.

Kahneman D, Tversky A. Prospect theory: an analysis of decision under risk. Econometrica. 1979;47(2):26391.

Kale SS. Current reforms: the politics of policy change in India's electricity sector. Pacific Affairs. 2004;77(3): 467-91.

Katzenstein PJ. Small states in world markets: industrial policy in Europe. Ithaca, N.Y: Cornell University Press; 1985.

Kaufman RR, Segura-Ubiergo A. Globalization, domestic politics, and social spending in Latin America: a time-series cross-section analysis, 1973-97. World Politics. 2001;53(4):553-87.

Kemp P, editor. Housing allowances in comparative perspective. Bristol, U.K: Policy Press; 2007.

Korpi W. The democratic class struggle. London; Boston: Routledge \& K. Paul; 1983.

Kuzio T. Populism in Ukraine in a comparative European context. Problems of Post-Communism. 2010;57(6): 3-18.

Lipton M. Why poor people stay poor: a study of urban bias in world development. London: Temple Smith; 1977.

Marchionni M, Battistón D, Crosta F, Alejo J. Sostener precios con subsidios. Cuánto cuesta y cuál es su incidencia distributiva en la Argentina. World Bank. Working Paper; 2008a.

Marchionni M, Sosa Escudero W, Alejo J. La incidencia distributiva del acceso, gasto y consumo de los servicios públicos. CEDLAS. Working Paper 67; 2008b.

Mettler S. Soldiers to citizens: the G.I. bill and the making of the greatest generation. Oxford; New York: Oxford University Press; 2005.

Mettler S. The submerged state: how invisible government policies undermine American democracy. Chicago: University of Chicago Press; 2011.

Mitra P, Atoyan R. Ukraine gas pricing policy: distributional consequences of tariff increases. IMF WP/12/ 247; 2012. 
Montenegro M. Es la eKonomía [sic], estúpido: la historia secreta de las decisiones, trampas y falacias del kirchnerismo. Buenos Aires: Planeta; 2011.

Murillo MV. Political competition, partisanship, and policymaking in Latin American public utilities. New York: Cambridge University Press; 2009.

OPSM. Los servicios públicos privatizados en el marco de la post-devaluación. Buenos Aires: OPSM; 2003.

OPSM. Percepciones públicas acerca del funcionamiento de los servicios públicos y el desempeño del sector de empresas privatizadas. Buenos Aires: OPSM; 2006.

Pampel FC, Williamson JB. Age, class, politics, and the welfare state. Cambridge [England]; New York: Cambridge University Press; 1989.

Pierson P. Dismantling the welfare state?: Reagan, Thatcher, and the politics of retrenchment. Cambridge, England; New York: Cambridge University Press; 1995.

Pierson P. The new politics of the welfare state. World Politics. 1996;48(02):143-79.

Post AE. Foreign and domestic investment in Argentina: the politics of privatized infrastructure. Cambridge: Cambridge University Press; 2014a.

Post AE. Home court advantage investor type and contractual resilience in the argentine water sector. Politics \& Society. 2014b;42(1):107-32.

Rhodes S. Social movements and free-market capitalism in Latin America: telecommunications privatization and the rise of consumer protest. Albany: State University of New York Press; 2006.

Rudra N. Globalization and the decline of the welfare state in less-developed countries. International Organization. 2002;56(2):411-45.

Savedoff WD, Spiller PT. Spilled water: institutional commitment in the provision of water services. Washington, D.C: Inter-American Development Bank; 1999.

Segura-Ubiergo A. The political economy of the welfare state in Latin America: globalization, democracy, and development. Cambridge; New York: Cambridge University Press; 2007.

Tongia R. The political economy of Indian power sector reforms. In: Victor DG, Heller TC, editors. The political economy of power sector reform: the experiences of five major developing countries. Cambridge; New York: Cambridge University Press; 2007. p. 109-74.

UNDP. Energy subsidies in the Arab world. 2012.

Victor D. The politics of fossil-fuel subsidies. Geneva: International Institute for Sustainable Development; 2009.

Weaver RK. The politics of blame avoidance. Journal of Public Policy. 1986;6(04):371-98.

Weaver RK. Automatic government: the politics of indexation. Washington, D.C: Brookings Institution; 1988.

Weyland K. Risk taking in Latin American economic restructuring: lessons from prospect theory. International Studies Quarterly. 1996;40(2):185-207.

Wibbels E. Dependency revisited: international markets, business cycles, and social spending in the developing world. International Organization. 2006;60(2):433-68.

World Bank. Water, electricity, and the poor: who benefits from utility subsidies? Washington, DC: World Bank; 2005.

Tomás Bril-Mascarenhas is a Ph.D. candidate in political science at the University of California, Berkeley. $\mathrm{He}$ is currently working on a comparative political economy study of financial systems and investment patterns in Latin America, with a focus on Argentina, Brazil, and Chile. His earlier work on party system collapse was published by Desarrollo Económico.

Alison E. Post is an Assistant Professor of Political Science and Global Metropolitan Studies at the University of California, Berkeley. Her research focuses on comparative political economy and comparative urban politics, with a particular focus on urban infrastructure. 